\title{
Desain dan Analisa Sistem Magang di Prodi Teknik Informasi Universitas Widya Kartika Menggunakan UML
}

\author{
Indra Budi Trisno ${ }^{1 *}$, Yulius Hari ${ }^{1}$ \\ ${ }^{1}$ Universitas Widya Kartika \\ J1. Sutorejo Prima Utara II/ 1, Surabaya 60113 \\ Corresponding author‘s e-mail: indrabt@gmail.com
}

\begin{abstract}
Abstrak - Prodi Teknik Informatika merupakan salah satu prodi yang terdapat pada Universitas Widya Kartika Surabaya. Mahasiswa yang mengambil jurusan ini, diharuskan untuk melakukan magang selama kurang lebih 200 jam di perusahaan. Saat ini dokumentasi magang masih dilakukan secara manual. Penulis menggunakan metode UML untuk membuat analisa sistem magang ini. Tool-tool UML yang digunakan adalah Class Diagram, Sequence Diagram serta Activity Diagram. Pembuatan analisa dan desain sistem ini akan memudahkan penulis untuk melakukan implementasi analisa menjadi program, karena banyak Bahasa pemrograman sudah mendukung konsep Object Oriented Programming.
\end{abstract}

Kata kunci: Sistem Magang, Universitas Widya Kartika, UML.

Abstract - Informatic Engineering is one of available study program at Widya Kartika University, Surabaya. Each student that takes this study program has to take internship as long as minimum 200 hours at any company. The process from registering until submitting internship grade has been done manually. The author applied UML in order to develop a blueprint of the internship system. UML Diagram tools will be used are Class Diagram, Sequence Diagram and Activity Diagram. Applying UML will make development of the system will be easy, because a lot of programming languages nowadays support Object Oriented Programming.

Kata kunci: Internship system, Universitas Widya Kartika, UML.

\section{Pendahuluan}

Universitas Widya Kartika didirikan pada tahun 1986 oleh Yayasan Pendidikan Pengajaran Indonesia [1]. Pengurus yang mendirikan universitas ini adalah Bpk. Moch. Achwan, SH (Ketua), Bpk. Widyanto Tedja, SH, Bpk. Dipl. Ing. Johannes Kumala, Bpk. Hidayat, Bpk. Yusuf Arief Yudoyono, dan Bpk. Soeroto dan Bpk Oemar (alm). Pendirian universitas ini berdasarkan Surat Keputusan Menteri Pendidikan dan Kebudayaan Republik Indonesia Nomer 0728/O/1986. Kampus universitas ini terletak di Jl. Sutorejo Prima Utara II/1, Jawa Timur, Surabaya.

Universitas Widya Kartika memiliki 3 Fakultas, yaitu Fakultas Teknik, Fakultas Ekonomi, dan Fakultas Bahasa dan Sastra [2]. Fakultas Teknik memiliki empat program studi, yaitu : Teknik Elektro (S1), Arsitektur (S1), Teknik Informatika (S1), dan Teknik Sipil (S1). Fakultas Ekonomi memiliki dua program studi, yaitu Akutansi (S1) dan Manajemen (S1). Fakultas Bahasa dan Sastra memiliki dua program studi, yaitu Pendidikan Bahasa Mandarin (S1) dan Sastra Inggris (S1).

Salah satu factor yang dapat mempengaruhi keberhasilan dalam suatu organisasi adalah Sistem Informasi dan Teknologi Informasi (SI/TI) [3]. Teknologi Informasi juga dapat membantu operasi organisasi menjadi lebih efisien [4]. Universitas Widya Kartika menerapkan Teknologi Informasi pada berbagai bidang. Sebagai contoh penerapan E-Learning yang beralamatkan di dion.widyakartika.ac.id. Pembuatan website yang bertujuan untuk mengelola serta menampilkan riset dan pengabdian yang dilakukan oleh para dosen Universitas Widya Kartika yang beralamatkan di lppm.widyakartika.ac.id. Pembuatan website yang menampilkan informasi-informasi yang dapat diakses oleh masyarakat. Website Universitas Widya Kartika beralamatkan di widyakartika.ac.id.

Meskipun Universitas Widya Kartika menerapkan Teknologi Informasi pada berbagai hal, ada beberapa yang masih belum menggunakan Sistem Informasi / Teknologi Informasi. Salah satunya adalah pengelolaan program magang di Prodi Teknik Informatika. Beberapa hal yang sering terjadi akibat tidak digunakannya Sistem Informasi untuk magangi ini adalah : dokumen yang sering hilang, kesulitan dalam mencari suatu informasi yang dibutuhkan, dan duplikasi dokumen.

Untuk mengatasi hal ini, maka penulis beserta team berencana membuat sistem informasi menggunakan teknologi web. Tahap analisa dan desain sistem menggunakan beberapa diagram yang terdapat pada Unified Modeling Language (UML), yaitu Class Diagram, Sequence Diagram, dan Activity Diagram. 


\section{Tinjauan Pustaka}

\subsection{Hirarki Informasi}

Tiga istilah yang sering muncul yang berkaitan dengan informasi adalah informasi, data dan knowledge. Ketiga istilah ini sering tertukar. Penjelasan perbedaan ketiga istilah ini dapat dilihat pada Tabel 1. Perbedaan antara Data, Information dan Knowledge.

\begin{tabular}{|c|c|c|c|}
\hline & Data & Information & Knowledge \\
\hline Definisi & $\begin{array}{l}\text { Pengamatan sederhana } \\
\text { dari suatu kondisi atau } \\
\text { keadaan di dunia. }\end{array}$ & $\begin{array}{l}\text { Data yang diolah untuk } \\
\text { suatu tujuan. }\end{array}$ & $\begin{array}{l}\text { Informasi } \\
\text { didapatkan dari pikiran } \\
\text { manusia. Informasi ini } \\
\text { meliputi : refleksi, } \\
\text { sintesis dan context. } \\
\end{array}$ \\
\hline Karakteristik & 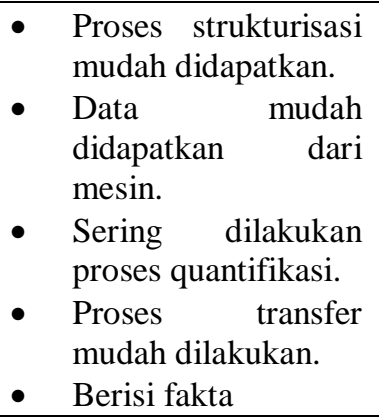 & 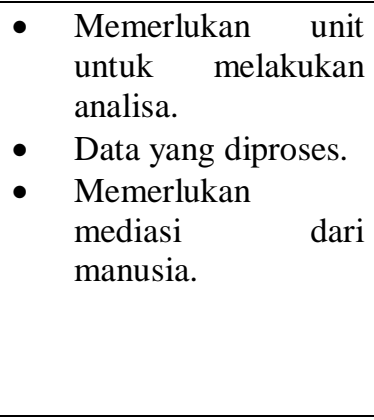 & 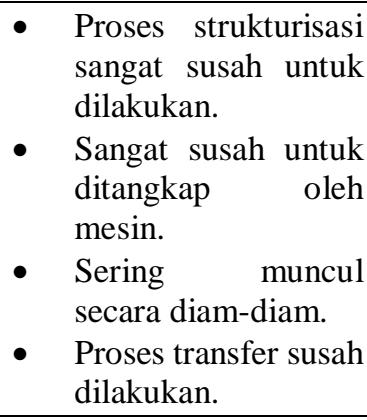 \\
\hline Contoh & $\begin{array}{l}\text { laporan inventaris dari } \\
\text { suatu perusahaan } \\
\text { manufacture besar yang } \\
\text { dikirim ke CEOnya } \\
\text { setiap hari. }\end{array}$ & $\begin{array}{l}\text { Laporan inventaris dari } \\
\text { barang-barang yang } \\
\text { dibawah target penjualan } \\
\text { yang di kirim pada } \\
\text { manager inventory. } \\
\text { Laporan ini dikirimkan } \\
\text { setiap hari. }\end{array}$ & $\begin{array}{l}\text { Pengetahuan manajer } \\
\text { inventaris tentang } \\
\text { item mana yang perlu } \\
\text { dipesan ulang? } \\
\text { berdasarkan laporan } \\
\text { persediaan harian, } \\
\text { pemogokan buruh yang } \\
\text { diantisipasi, dan } \\
\text { banjir di Brasil yang } \\
\text { mempengaruhi } \\
\text { pasokan komponen } \\
\text { utama }\end{array}$ \\
\hline
\end{tabular}

Tabel 1. Perbedaan antara Data, Information dan Knowledge [5]

\subsection{Sistem Informasi}

Sistem Informasi adalah komponen-komponen yang melakukan proses pengambilan, pengumpulan, pemrosesan, penyimpanan dan pendistribusian informasi untuk mendukung pengambilan keputusan dan pengendalian dalam sebuah organisasi [6][7]. Information System memiliki informasi tentang orang-orang, tempat-tempat dan segala sesuatu yang berkaitan dengan organisasi tersebut beserta dengan lingkungan yang terlibat di dalam organisasi tersebut.

Sistem Informasi sering disalah artikan dengan Teknologi Informasi (Information Technology). Teknologi Informasi adalah study, desain, implementasi, support dari Sistem Informasi yang berbasiskan komputer [8]. Teknologi Informasi ini meliputi hardware dan software yang dibutuhkan oleh organisasi untuk mencapai tujuan dari organisasi / perusahaan tersebut. Sedangkan sistem informasi tidak hanya meliputi hardware, software dan jaringan yang membentuk sistem dari suatu perusahaan, tetapi juga user-user yang menjalankan sistem tersebut.

2.3. Unified Modeling Language

Unified Modeling Language (UML) adalah sebuah metode perancangan sistem yang menggunakan pendekatan analisa berbasiskan objek (Object Oriented Design) [9]. UML memiliki beberapa diagram yang dapat digunakan selama proses perancangan sistem. Beberapa diagram yang terdapat pada UML adalah sebagai berikut : 
1. Class Diagram

Class Diagram adalah sebuah diagram yang menggambarkan tipe-tipe objek yang berada di dalam sistem, lengkap dengan relasi-relasi antara mereka [10]. Class diagram juga menunjukkan operasioperasi dan property-property yang dimiliki oleh masing-masing class.

2. Sequence Diagram

Sequence Diagram adalah salah satu diagram yang terdapat pada UML. Sequence Diagram merupakan diagram yang menggambarkan bagaimana dan bagaimana urutan suatu object-object dalam suatu group dapat bekerja secara bersama-sama [11]. Sequence diagram bisa juga disebut sebagai event diagram atau event scenario.

3. Activity Diagram

Activity Diagram adalah salah satu diagram yang juga terdapat pada UML. Activity Diagram berguna untuk menunjukkan aliran dari suatu aktivitas ke aktivitas lainnya [12]. Activity Diagram juga dapat membantu orang-orang yang terlibat dalam pembuatan sistem, baik dari sisi pengembang (developer) maupun dari sisi pengguna (end user) supaya mampu memiliki pemahaman yang sama [13].

\section{Metode Penelitian}

Metode penelitian terdiri dari beberapa tahap, yaitu :

1. Pengumpulan informasi dan studi Pustaka

Pada tahap ini dilakukan pengumpulan informasi mengenai hal-hal yang berkaitan dengan kerja praktek yang akan dibuat sistemnya. Proses kerja praktek di Prodi Teknik Informatika terdiri dari beberapa tahap sebagai berikut :

1. Proses perwalian untuk pengambilan mata kuliah magang.

Mahasiswa diwajibkan untuk melakukan input mata kuliah magang yang dilakukan pada awal semester. Mahasiswa yang mengambil magang diwajibkan sudah menempuh minimal 90 SKS.

2. Proses pencarian perusahaan.

Mahasiswa melakukan pencarian perusahaan untuk melakukan magang. Proses ini bisa dilakukan secara mandiri oleh mahasiswa, atau mahasiswa bisa melakukan magang di perusahaan-perusahaan yang sudah melakukan kerja sama dengan prodi / universitas.

3. Proses pengiriman surat ke perusahaan tempat magang mahasiswa.

Mahasiswa yang sudah mendapatkan tempat magang, dapat meminta surat pengantar yang akan diberikan kepada perusahaan tempat mereka magang. Pembuatan surat ini dilakukan oleh TU Fakultas.

4. Proses pengiriman surat dari perusahaan ke prodi.

Pihak perusahaan akan mengirimkan surat balasan kepada TU fakultas.

5. Proses penentuan dosen pembimbing.

Tahap ini adalah tahap penentuan dosen pembimbing bagi mahasiswa yang mengambil magang. Ada dua cara dalam proses penentuan dosen pembimbing :

i. Cara pertama adalah mahasiswa mengajukan dosen pembimbing. Koordinator magang akan melihat jumlah mahasiswa yang dibimbing oleh dosen yang bersangkutan dan juga akan mengecek apakah dosen yang bersangkutan bersedia untuk menjadi dosen pembimbing. Apabila jumlah mahasiswa bimbingan masih kurang dan dosen tersebut bersedia, maka dosen tersebut akan menjadi pembimbing mahasiswa tersebut.

ii. Cara kedua adalah koordinator magang akan menentukan dosen pembimbing bagi mahasiswa.

6. Tahap keenam adalah tahap pengiriman form absensi magang dan beberapa dokumen yang menjadi persyaratan magang

Pada tahap ini mahasiswa diwajibkan untuk mengisi beberapa dokumen yang harus diisi selama proses magang berlangsung. Selain itu mahasiswa juga diwajibkan untuk mengisi log harian yang berisi pekerjaan-pekerjaan apa saja yang dilakukan pada waktu magang.

7. Proses pemberian nilai oleh dosen pembimbing dan pembimbing lapangan.

Pada tahap ini mahasiswa sudah menyelesaikan proses magang, sudah mengisi dokumen-dokumen yang diperlukan selama magang. Pemberian nilai akan dilakukan oleh dosen pembimbing dan pembimbing lapangan. Presentase nilai akhir untuk magang ini adalah 50\% nilai diambil dari dosen pembimbing dan 50\% dari pembimbing lapangan.Proses pemberian nilai oleh dosen pembimbing dan pembimbing lapangan.

2. Studi Pustaka digunakan untuk pengumpulan informasi mengenai metode analisa dan desain sistem yang akan digunakan.

3. Pembuatan Class Diagram, Sequence Diagram dan Activity Diagram untuk analisa dan desain Sistem 


\section{Hasil dan Pembahasan}

Pada bagian ini akan dibahas mengenai desain dan analisa sistem yang dibuat dalam bentuk Class Diagram, Sequence Diagram dan Activity Diagram sesuai dengan studi kasus magang yang terdapat pada Prodi Teknik Informatika Universitas Widya Kartika.

4.1. Class Diagram

Class Diagram untuk sistem magang di Prodi Teknik Informatika Universitas Widya Kartika memiliki 11 class, yaitu :

1. Class Mahasiswa.

Class Mahasiswa merupakan class yang digunakan untuk menyimpan semua data mahasiswa yang mengambil program magang. Class ini berisi attribute-attribute sebagai berikut : NRP, jenis kelamin yang berisi dua pilihan, yaitu laki-laki dan perempuan. Attribute berikutnya adalah nama, alamat, nomor hp, nomor wa, dan jumlah sks. Setiap attribute ini memiliki sifat private. Method get dan set dibuat untuk masing-masing attribute. Kedua method ini bersifat public. Method get digunakan untuk mengambil nilai dari attribute tertentu, sedangkan method set digunakan untuk melakukan pemberian nilai untuk attribute tertentu. Selain method get dan set, class mahasiswa juga memiliki 4 method lainnya, yaitu method insert, update, delete, dan search. Method insert digunakan untuk memasukkan nilai data baru. Method update digunakan untuk melakukan update data yang sudah ada. Method delete digunakan untuk menghapus data. Method search digunakan untuk mencari suatu data tertentu.

2. Class Dosen Pembimbing.

Class Dosen Pembimbing merupakan class yang digunakan untuk menyimpan semua data dosen pembimbing yang membimbing mahasiswa yang mengambil program magang. Class ini berisi attribute-attribute sebagai berikut : NIP, nama, alamat, nomor hp, dan nomor WA. Setiap attribute ini memiliki sifat private. Method get dan set dibuat untuk masing-masing attribute. Kedua method ini bersifat public. Method get digunakan untuk mengambil nilai dari attribute tertentu, sedangkan method set digunakan untuk melakukan pemberian nilai untuk attribute tertentu. Selain method get dan set, class ini juga memiliki 4 method lainnya, yaitu method insert, update, delete, dan search. Method insert digunakan untuk memasukkan nilai data baru. Method update digunakan untuk melakukan update data yang sudah ada. Method delete digunakan untuk menghapus data. Method search digunakan untuk mencari suatu data tertentu.

3. Class Perusahaan merupakan class yang digunakan untuk menyimpan data perusahaan tempat mahasiswa-mahasiswa melakukan magang. Class ini berisi attribute-attribute sebagai berikut : kode, nama, alamat, nomor telpon, nomor fax, email, website dan nomor WA. Setiap attribute ini memiliki sifat private. Method get dan set dibuat untuk masing-masing attribute. Kedua method ini bersifat public. Method get digunakan untuk mengambil nilai dari attribute tertentu, sedangkan method set digunakan untuk melakukan pemberian nilai untuk attribute tertentu. Selain method get dan set, class ini juga memiliki 4 method lainnya, yaitu method insert, update, delete, dan search. Method insert digunakan untuk memasukkan nilai data baru. Method update digunakan untuk melakukan update data yang sudah ada. Method delete digunakan untuk menghapus data. Method search digunakan untuk mencari suatu data tertentu.

4. Class Pembimbing Lapangan

Class Pembimbing Lapangan merupakan class yang digunakan untuk menyimpan data pembimbing lapangan tempat mahasiswa-mahasiswa melakukan magang. Class ini berisi attribute-attribute sebagai berikut : kode, nama, nomor telpon dan nomor WA. Setiap attribute ini memiliki sifat private. Method get dan set dibuat untuk masing-masing attribute. Kedua method ini bersifat public. Method get digunakan untuk mengambil nilai dari attribute tertentu, sedangkan method set digunakan untuk melakukan pemberian nilai untuk attribute tertentu. Selain method get dan set, class ini juga memiliki 4 method lainnya, yaitu method insert, update, delete, dan search. Method insert digunakan untuk memasukkan nilai data baru. Method update digunakan untuk melakukan update data yang sudah ada. Method delete digunakan untuk menghapus data. Method search digunakan untuk mencari suatu data tertentu.

5. Class Staff TU.

Class Staff TU merupakan class yang digunakan untuk menyimpan data staff TU yang melakukan proses administrasi magang. Class ini berisi attribute-attribute sebagai berikut : NIP, nama, alamat, nomor WA, nomor HP. Setiap attribute ini memiliki sifat private. Method get dan set dibuat untuk masing-masing attribute. Kedua method ini bersifat public. Method get digunakan untuk mengambil nilai dari attribute tertentu, sedangkan method set digunakan untuk 
melakukan pemberian nilai untuk attribute tertentu. Selain method get dan set, class ini juga memiliki 4 method lainnya, yaitu method insert, update, delete, dan search. Method insert digunakan untuk memasukkan nilai data baru. Method update digunakan untuk melakukan update data yang sudah ada. Method delete digunakan untuk menghapus data. Method search digunakan untuk mencari suatu data tertentu.

6. Class Surat Permohonan.

Class Surat Permohonan merupakan class yang digunakan untuk menyimpan data surat permohonan untuk menerima mahasiswa menjadi mahasiswa magang di suatu perusahaan. Class ini berisi attribute-attribute sebagai berikut : kode, tanggal, jam, isi surat. Setiap attribute ini memiliki sifat private. Method get dan set dibuat untuk masing-masing attribute. Kedua method ini bersifat public. Method get digunakan untuk mengambil nilai dari attribute tertentu, sedangkan method set digunakan untuk melakukan pemberian nilai untuk attribute tertentu. Selain method get dan set, class ini juga memiliki 4 method lainnya, yaitu method insert, update, delete, dan search. Method insert digunakan untuk memasukkan nilai data baru. Method update digunakan untuk melakukan update data yang sudah ada. Method delete digunakan untuk menghapus data. Method search digunakan untuk mencari suatu data tertentu.

7. Class Surat Balasan.

Class Surat Balasan merupakan class yang digunakan untuk menyimpan data surat balasan dari perusahaan. Class ini berisi attribute-attribute sebagai berikut : kode, tanggal, jam, isi surat, status permohonan yang dapat berisi salah satu dari dua nilai yang tersedia, yaitu disetujui dan ditolak. Setiap attribute ini memiliki sifat private. Method get dan set dibuat untuk masingmasing attribute. Kedua method ini bersifat public. Method get digunakan untuk mengambil nilai dari attribute tertentu, sedangkan method set digunakan untuk melakukan pemberian nilai untuk attribute tertentu. Selain method get dan set, class ini juga memiliki 4 method lainnya, yaitu method insert, update, delete, dan search. Method insert digunakan untuk memasukkan nilai data baru. Method update digunakan untuk melakukan update data yang sudah ada. Method delete digunakan untuk menghapus data. Method search digunakan untuk mencari suatu data tertentu.

8. Class Log Harian.

Class Log Harian merupakan class yang digunakan untuk menyimpan data pekerjaan yang dilakukan oleh mahasiswa setiap hari di perusahaan. Class ini berisi attribute-attribute sebagai berikut : kode, tanggal, jam, keterangan, bukti, dan status pekerjaan. Attribute bukti digunakan untuk menyimpan bukti bahwa mahasiswa sudah melakukan pekerjaan sesuai dengan log yang dicatat. Bukti ini adalah berupa foto. Attribute status digunakan untuk menyatakan apakah pembimbing lapangan sudah mengetahui pekerjaan yang dilakukan oleh mahasiswa magang. Status ini bisa berisi disetujui atau ditolak. Setiap attribute ini memiliki sifat private. Method get dan set dibuat untuk masing-masing attribute. Kedua method ini bersifat public. Method get digunakan untuk mengambil nilai dari attribute tertentu, sedangkan method set digunakan untuk melakukan pemberian nilai untuk attribute tertentu. Selain method get dan set, class ini juga memiliki 4 method lainnya, yaitu method insert, update, delete, dan search. Method insert digunakan untuk memasukkan nilai data baru. Method update digunakan untuk melakukan update data yang sudah ada. Method delete digunakan untuk menghapus data. Method search digunakan untuk mencari suatu data tertentu.

9. Class Form Konsultasi.

Class Form Konsultasi merupakan class yang digunakan untuk menyimpan data konsultasi antara mahasiswa dan dosen pembimbing. Class ini berisi attribute-attribute sebagai berikut : kode, tanggal, jam, keterangan. Setiap attribute ini memiliki sifat private. Method get dan set dibuat untuk masing-masing attribute. Kedua method ini bersifat public. Method get digunakan untuk mengambil nilai dari attribute tertentu, sedangkan method set digunakan untuk melakukan pemberian nilai untuk attribute tertentu. Selain method get dan set, class ini juga memiliki 4 method lainnya, yaitu method insert, update, delete, dan search. Method insert digunakan untuk memasukkan nilai data baru. Method update digunakan untuk melakukan update data yang sudah ada. Method delete digunakan untuk menghapus data. Method search digunakan untuk mencari suatu data tertentu.

10. Class Form Penilaian Pembimbing Lapangan.

Class Form Penilaian Pembimbing Lapangan merupakan class yang digunakan untuk menyimpan data penilaian yang diberikan oleh pembimbing lapangan kepada mahasiswa. Class ini berisi attribute-attribute sebagai berikut : kode, tanggal, jam, nilai (memiliki skala antara 0- 
100), keterangan, saran untuk mahasiswa, dan saran untuk prodi. Setiap attribute ini memiliki sifat private. Method get dan set dibuat untuk masing-masing attribute. Kedua method ini bersifat public. Method get digunakan untuk mengambil nilai dari attribute tertentu, sedangkan method set digunakan untuk melakukan pemberian nilai untuk attribute tertentu. Selain method get dan set, class ini juga memiliki 4 method lainnya, yaitu method insert, update, delete, dan search. Method insert digunakan untuk memasukkan nilai data baru. Method update digunakan untuk melakukan update data yang sudah ada. Method delete digunakan untuk menghapus data. Method search digunakan untuk mencari suatu data tertentu.

11. Class Form Penilaian Dosen.

Class Form Penilaian Dosen merupakan class yang digunakan untuk menyimpan data penilaian yang diberikan oleh dosen pembimbing kepada mahasiswa. Class ini berisi attribute-attribute sebagai berikut : kode, tanggal, jam, nilai (memiliki skala antara 0-100), keterangan. Setiap attribute ini memiliki sifat private. Method get dan set dibuat untuk masing-masing attribute. Kedua method ini bersifat public. Method get digunakan untuk mengambil nilai dari attribute tertentu, sedangkan method set digunakan untuk melakukan pemberian nilai untuk attribute tertentu. Selain method get dan set, class ini juga memiliki 4 method lainnya, yaitu method insert, update, delete, dan search. Method insert digunakan untuk memasukkan nilai data baru. Method update digunakan untuk melakukan update data yang sudah ada. Method delete digunakan untuk menghapus data. Method search digunakan untuk mencari suatu data tertentu.

Kumpulan class-class yang terdapat pada penjelasan diatas dapat dilihat pada Gambar 1. Class-class di Sistem Magang Prodi Teknik Informatika Universitas Widya Kartika.

Relasi antar class atau class diagram dapat dilihat pada Gambar 2. Class Diagram. Pada class diagram dapat dilihat bahwa staff TU dapat membuat lebih dari 1 surat permohonan yang ditujukan pada perusahaan. Perusahaan yang menerima surat permohonan akan membuat surat balasan bagi prodi. Pada surat balasan tersebut akan terdapat nama pembimbing lapangan yang akan membimbing mahasiswa selama proses magang. Nama pembimbing akan didapat, apabila mahasiswa diterima magang diperusahaan tersebut. Pada gambar juga disebutkan bahwa mahasiswa diwajibkan untuk mengisi log harian. Dimana log harian ini berisi aktivitasaktivitas yang dilakukan oleh mahasiswa selama magang di perusahaan tersebut. Aktivitas-aktivitas ini akan dicek oleh pembimbing lapangan, apakah disetujui atau ditolak. Mahasiswa juga diwajibkan untuk mengupload bukti kegiatan yang bisa berupa foto. Mahasiswa juga diwajibkan berkonsultasi pada dosen pembimbing dan mengisi form konsultasi. Dosen pembimbing akan melakukan pemeriksaan atas pekerjaan yang dilakukan oleh mahasiswa. Dosen pembimbing bisa menyetujui atau memberikan revisi atas pekerjaan-pekerjaan yang dilakukan oleh mahasiswa. Tahap penilaian akan dilakukan oleh dosen pembimbing dan pembimbing lapangan. Presentase nilai akhir adalah 50\% untuk dosen pembimbing dan 50\% untuk pembimbing lapangan. 

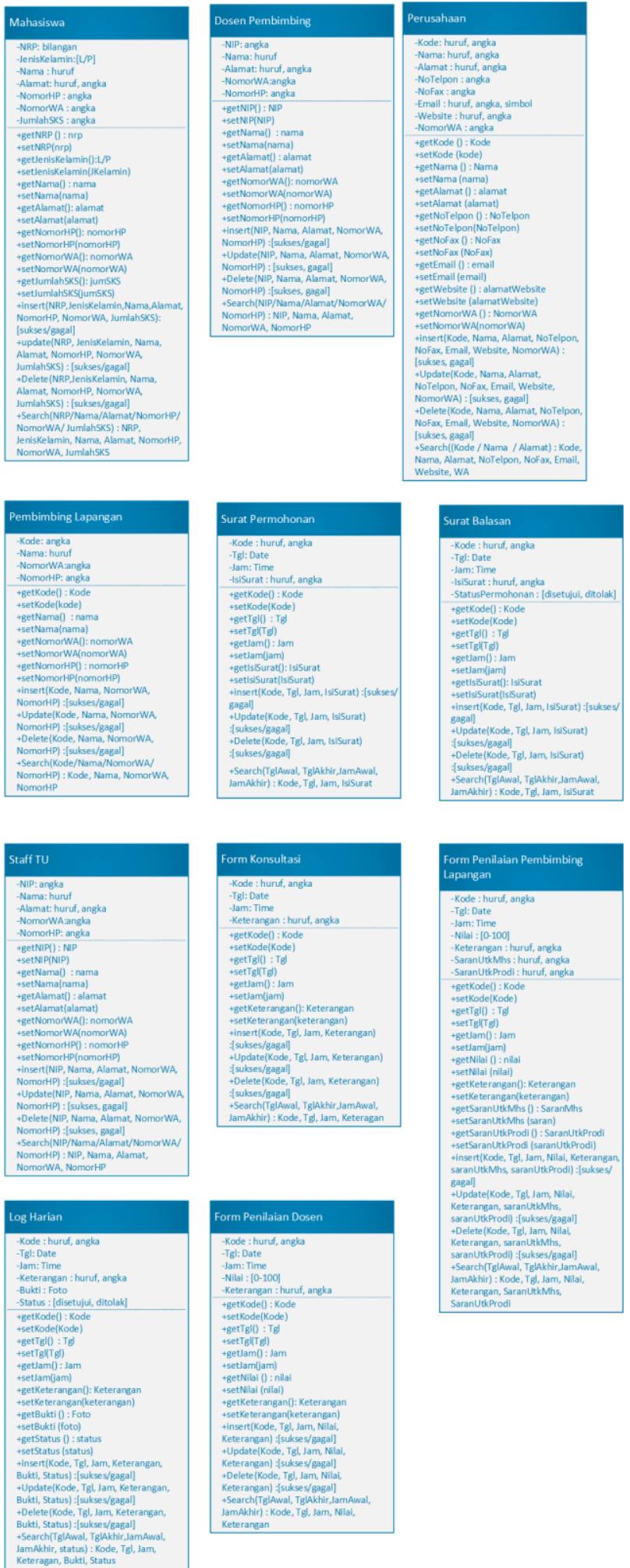

Gambar 1. Class-class di Sistem Magang Prodi Teknik Informatika Universitas Widya Kartika 


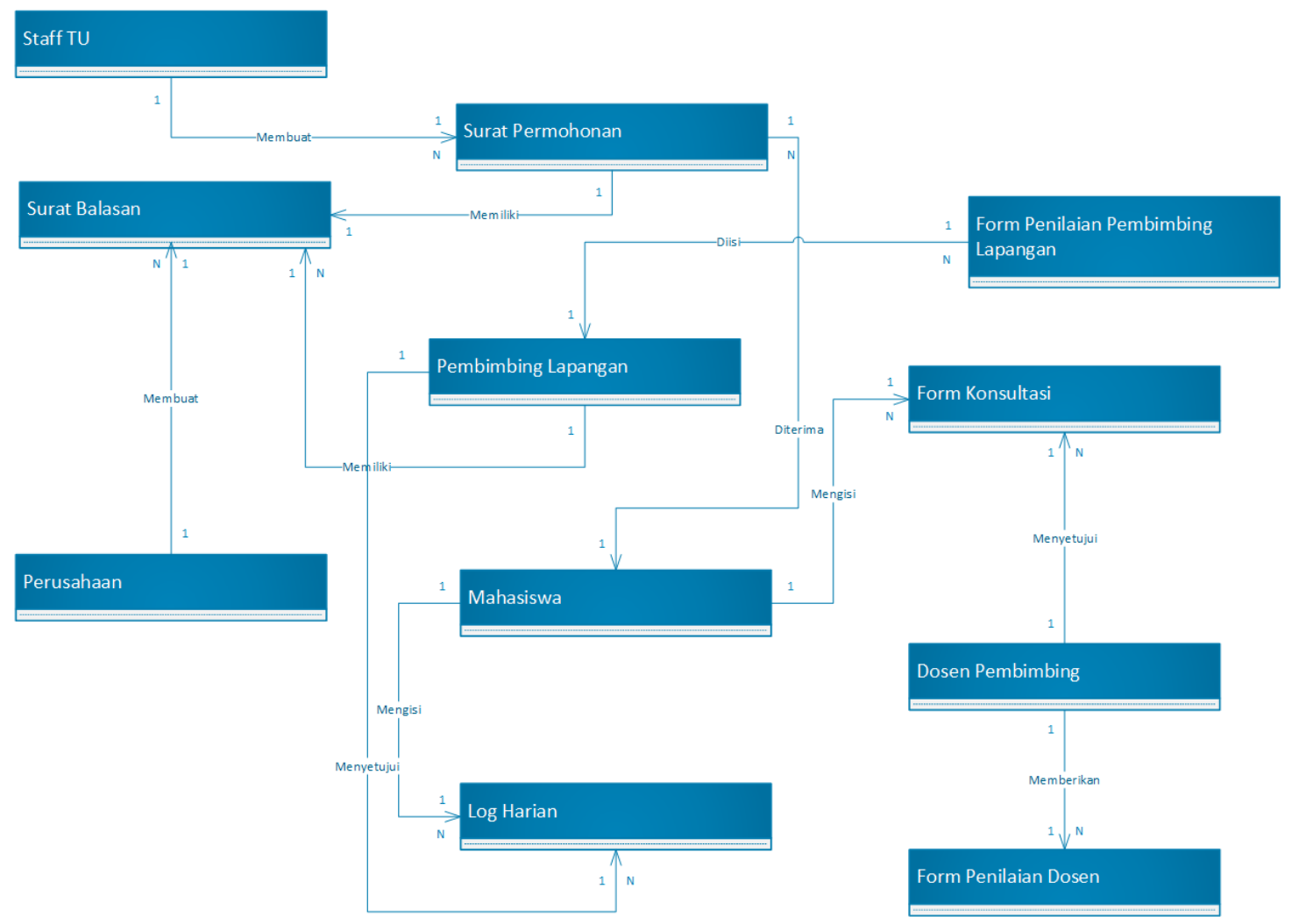

Gambar 2. Class Diagram

\subsection{Sequence Diagram}

Pada bagian ini akan dibahas sequence diagram yang terdapat pada penelitian ini. Penulis akan menampilkan 3 sequence diagram, yaitu sequence diagram login, sequence diagram pengisian log harian yang dilakukan oleh mahasiswa dan sequence diagram pemberian nilai akhir yang dilakukan oleh dosen pembimbing.

\subsubsection{Sequence Diagram Login.}

Sequence Diagram login digunakan untuk menggambarkan proses login yang dilakukan oleh para pengguna sistem. Pada sistem ini akan terdapat 4 pengguna, yaitu : administrator, dosen pembimbing, pembimbing lapangan, dan mahasiswa. Administrator disini akan dilakukan oleh koordinator magang. Sequence Diagram Login ditunjukkan oleh Gambar 3. Sequence Diagram Login

4.2.2. Sequence Diagram Pengisian Log Harian.

Sequence Diagram Pengisian Log Harian menggambarkan proses pengisian log harian yang dilakukan oleh mahasiswa. Proses ini membutuhkan beberapa data yang harus diinputkan oleh mahasiswa. Data-data tersebut adalah : tanggal, jam, keterangan, dan bukti. Kode pengisian, tanggal, dan jam akan digenerate otomatis oleh sistem. Sequence Diagram Pengisian Log harian ditunjukkan oleh Gambar 4. Pengisian Log Harian oleh Mahasiswa

4.2.3. Sequence Diagram Pemberian Nilai Akhir oleh Dosen Pembimbing.

Sequence Diagram Pemberian Nilai Akhir oleh Dosen Pembimbing menggambarkan proses pemberian nilai akhir yang dilakukan oleh dosen pembimbing. Dosen pembimbing diwajibkan untuk menginputkan data nilai yang memiliki range antara 0-100 dan keterangan. Attribut kode, tanggal, dan jam akan digenerate secara otomatis oleh sistem. Sequence Diagram Pemberian Nilai Akhir oleh Dosen Pembimbing ditunjukkan oleh Gambar 5. Sequence Diagram Pemberian Nilai oleh Dosen

\subsection{Activity Diagram}

Activity Diagram pada Gambar 6. Activity Diagram Pengajuan Magang oleh Mahasiswa menggambarkan proses yang terjadi pada waktu mahasiswa mengajukan magang sampai proses mahasiswa disetujui atau ditolak untuk magang pada suatu perusahaan. Mahasiswa diwajibkan untuk mencari tempat magang secara 
mandiri atau bisa meminta bantuan dari prodi. Mahasiswa yang sudah menemukan tempat magang meminta surat permohonan yang akan diberikan kepada perusahaan tempat mahasiswa tersebut magang. Perusahaan akan memberikan surat balasan yang menyatakan apakah mahasiswa tersebut diterima atau ditolak magang diperusahaan tersebut. Apabila disetujui, perusahaan akan mencantumkan nama pembimbing lapangan pada surat yang dikirimkan. Prodi akan menentukan dosen pembimbing berdasarkan input dari mahasiswa dan kapasitas bimbingan dosen yang bersangkutan.

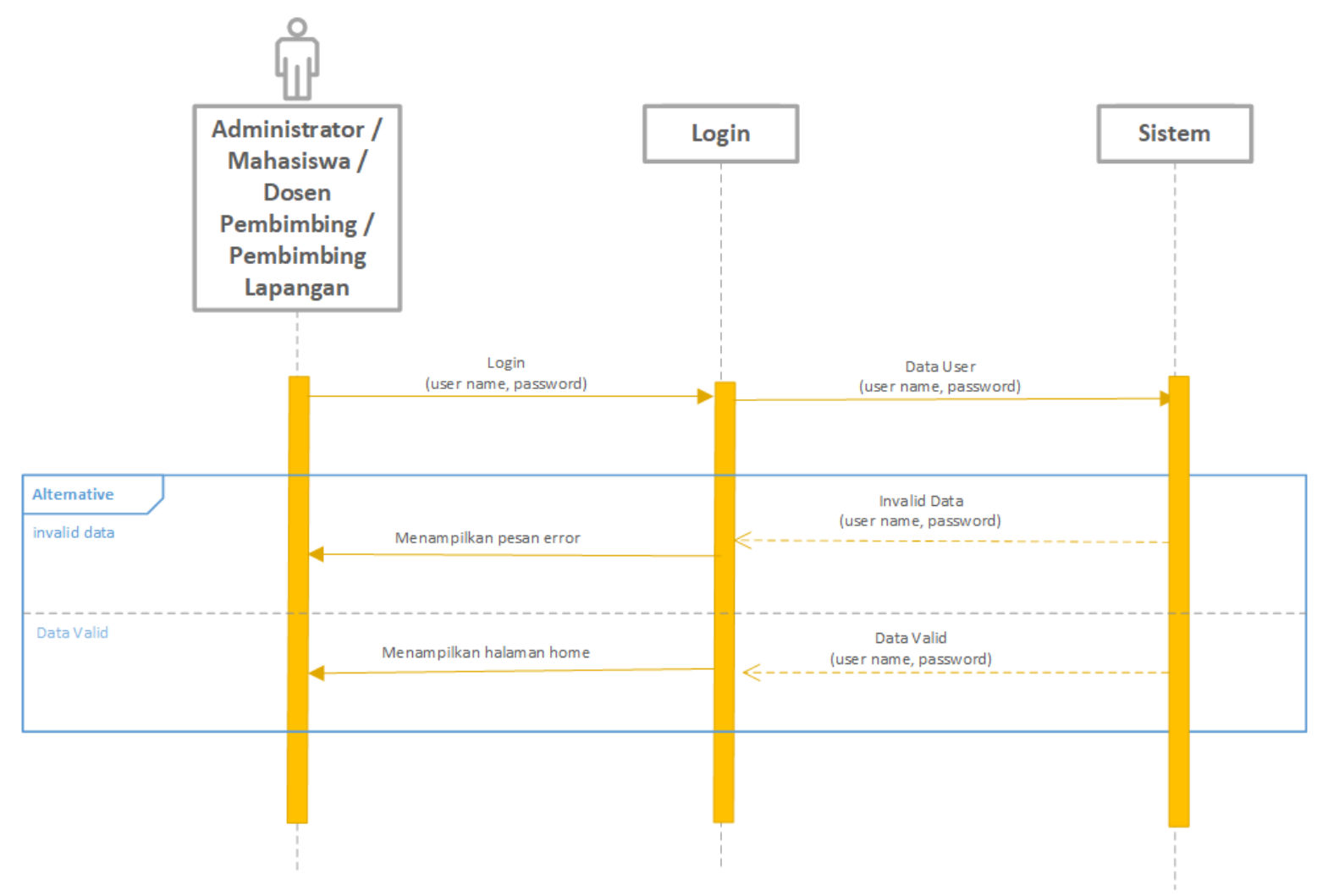

Gambar 3. Sequence Diagram Login 


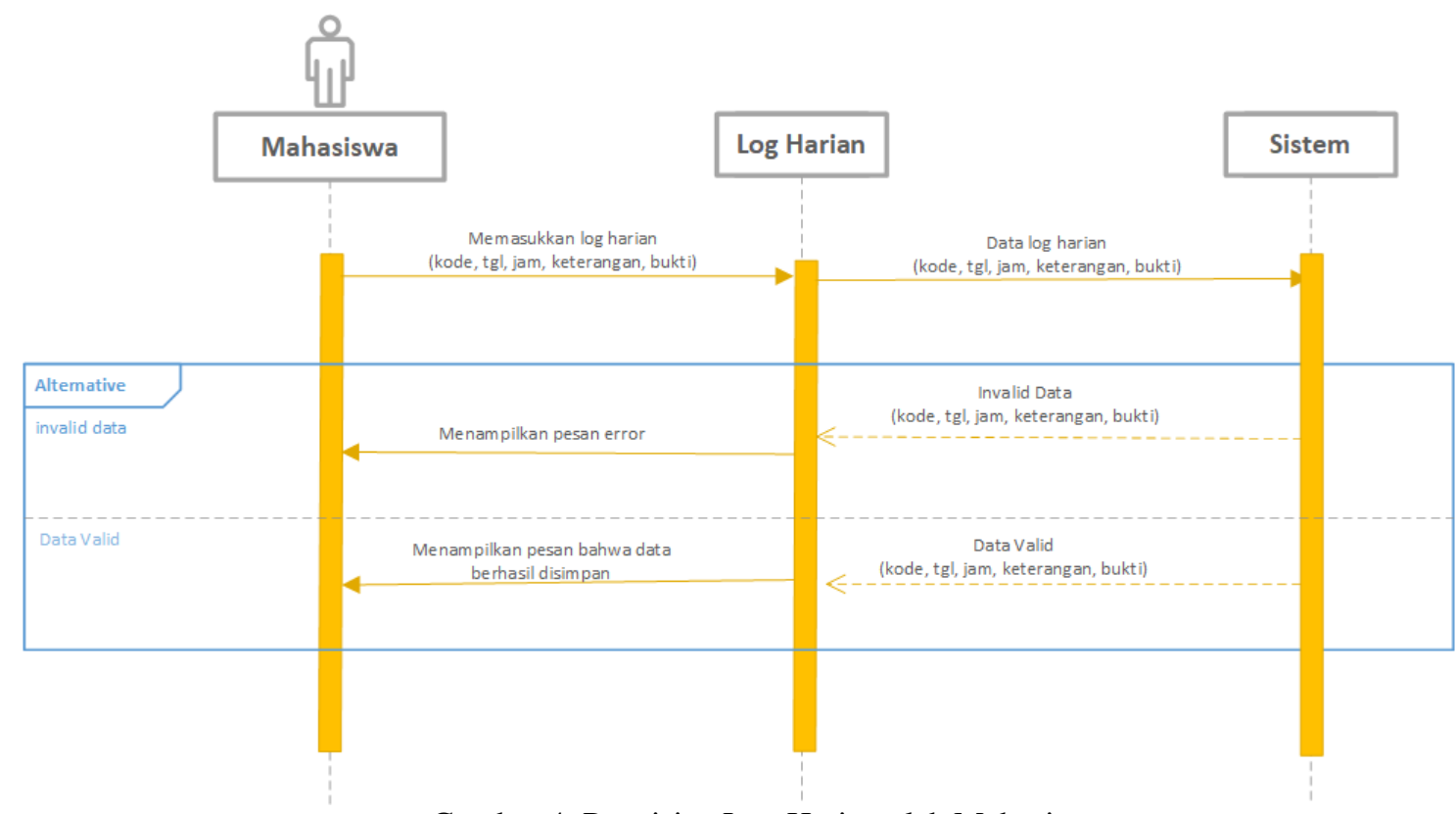

Gambar 4. Pengisian Log Harian oleh Mahasiswa

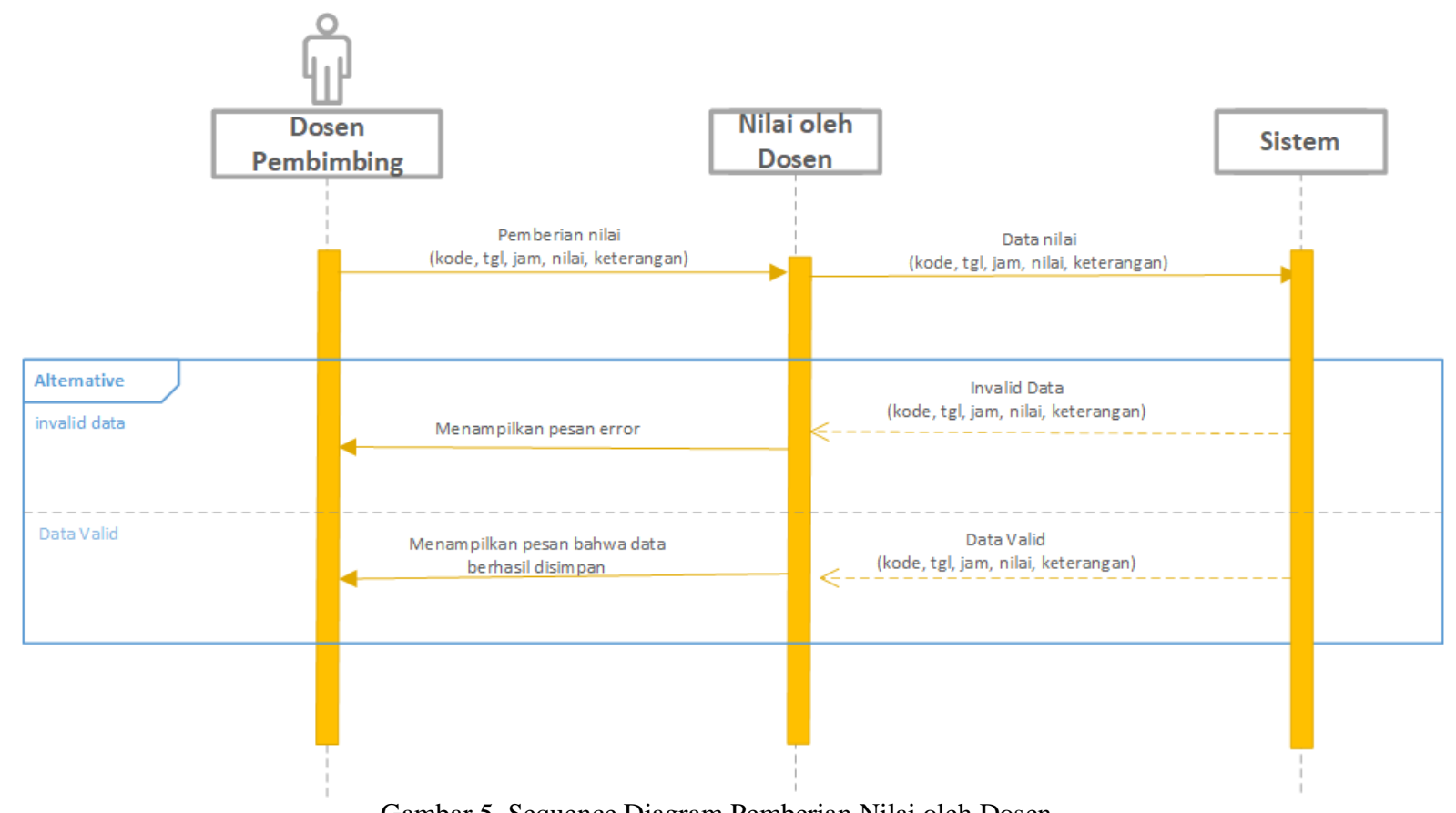

Gambar 5. Sequence Diagram Pemberian Nilai oleh Dosen 


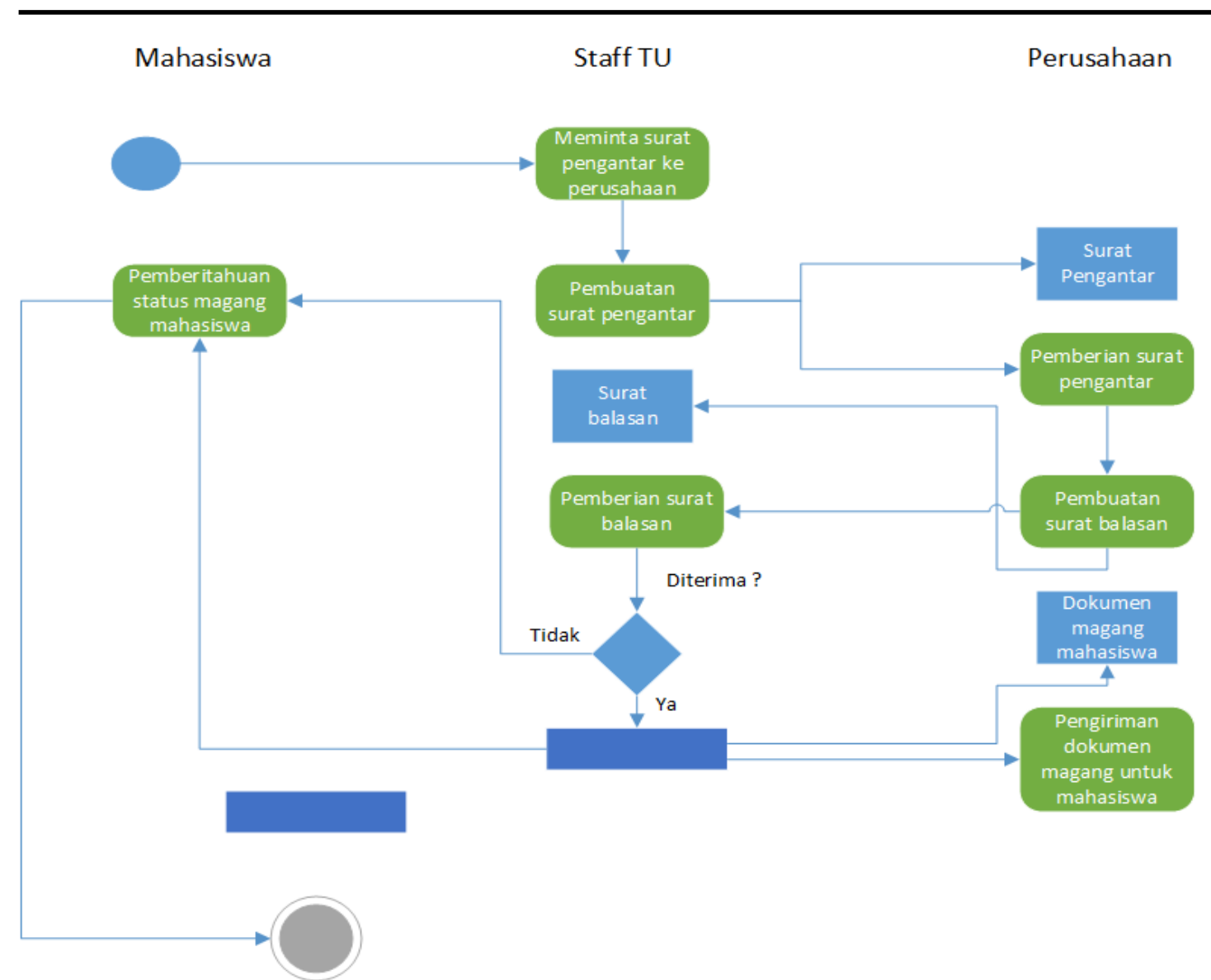

Gambar 6. Activity Diagram Pengajuan Magang oleh Mahasiswa

\section{Kesimpulan}

Analisa sistem menggunakan Unified Modeling Language (UML) sangat membantu untuk memperoleh gambaran sistem yang akan dibuat. Diagram ini juga akan memudahkan untuk melakukan komunikasi antara pihak developer / pembuat sistem dengan pengguna sistem (end user).

\section{Daftar Pustaka}

[1] M. J. B. H. P. S. Sembiring, “Uwika bertumbuh 2017-2021,” Surabaya, 2017.

[2] Widya Kartika, "Widya Kartika," 2021. .

[3] Y. Utami, A. Nugroho, and A. F. Wijaya, "Perencanaan Strategis Sistem Informasi dan Teknologi Informasi pada Dinas Perindustrian dan Tenaga Kerja Kota Salatiga," J. Teknol. Inf. dan Ilmu Komput., vol. 5 , no. 3, p. 253, 2018.

[4] M. A. Murtadho and D. F. Wahid, "Permasalahan implementasi sistem informasi di perguruan tinggi swasta," Regist. J. Ilm. Teknol. Sist. Inf., vol. 2, no. 1, pp. 17-21, 2016.

[5] K. E. Pearlson and C. S. Saunders, Managing and Using Information System: A Strategic Approach (6th edition), 6th ed. Wiley, 2016.

[6] K. C. Laudon and J. Laudon, IT Infrastructure and Emerging Technologies, 16th ed. Pearson, 2020.

[7] Z. Zulfan, B. Bahagia, H. Ahmadian, and D. Satria, "Sistem Informasi Data Korban Kebencanaan Berbasis Web," in Prosiding Seminar Nasional USM, 2017, vol. 1, no. 1.

[8] UAGC Staff Member, "Information Technology vs. Information Systems | UAGC | University of Arizona Global Campus," 2021. .

[9] S. Anardani, S. Riyanto, and D. Setiawan, "Perancangan Knowledge Management System Berbasis Web pada Tenaga Kependidikan Fakultas Teknik Universitas PGRI Madiun," J. Teknol. Inf. dan Ilmu Komput., vol. 8, no. 1, p. 77, 2021.

[10] M. Fowler, UML Distilled Third Edition A Brief Guide to the Standard Object Modeling Language. Addison Wesley, 2004. 
[11] LucidChart, "UML Sequence Diagram Tutorial | Lucidchart." .

[12] D. Damayanti and N. Nirmalasari, "Sistem Informasi Manajemen Penggajian dan Penilaian Kinerja Pegawai pada SMK Taman Siswa Lampung," J. Teknol. Inf. dan Ilmu Komput., vol. 6, no. 4, p. 389, 2019.

[13] LucidChart, "UML Activity Diagram Tutorial | Lucidchart." . 